\title{
Authority between Mask and Sign The Status of the Royal Body in Ancient Greece (Fourth to Second Centuries BCE)
}

\author{
Paul Cournarie
}

What is a royal body? It seems we cannot escape The King's Two Bodies, one of those works, rare in historiography, whose significance extends far beyond its original reach. Although historians have insisted on the specific focus of this study of the medieval roots of a fictio juris that appeared in sixteenth-century France and England, Ernst Kantorowicz himself saw it as a building block in a larger edifice. It was, he noted in the preface, a work which, "among other things," sought to show how a medieval political theology, "which mutatis mutandis was to remain valid until the twentieth century," could shed light on "the problem of what has been called "The Myth of the State."' Rather than the two bodies, scholars have generally addressed the question of their "separation," already invoked and explored within medieval intellectual constructions themselves, in order to focus on the royal "super-body."

\footnotetext{
This article was translated from the French by Troy Tice and edited by Chloe Morgan and Nicolas Barreyre. Unless otherwise indicated, English translations of Greek and Latin texts are cited from the Loeb Classical Library, published by Harvard University Press.

1. Ernst H. Kantorowicz, The King's Two Bodies: A Study in Mediaeval Political Theology (Princeton: Princeton University Press, 1957), viii and ix.

2. Claude Lefort, The Political Forms of Modern Society: Bureaucracy, Democracy, Totalitarianism (Cambridge: MIT Press, 1986), 302-6, reworked and systematized in Lefort, Democracy and Political Theory, trans. David Macey (Cambridge: Polity Press, 1988), 17-19, describes modern democracy as a separation of the two bodies. Conversely, Marcel Gauchet, "Des deux corps du roi au pouvoir sans corps. Christianisme et politique I," Le Débat 14, no. 7 (1981): 133-57, especially pp. 139 and 157, seeks to
} 
A similar effacement is found in the historiography that addresses the first of the two bodies, described as real or natural in contrast to the "super-body." Indeed, we are a long way from the original calls for an incarnated history, establishing the body as total historical fact $^{3}$; as well as from often-invoked philosophical authorities such as Maurice Merleau-Ponty or Michel Foucault, in whose work the central thematization of the body remained inhabited by a tension. ${ }^{4}$ The bias inherent in the history of representations condemns the history of the body to being only a history of the body divided. Parceled out among a variety of approaches (medical, social, political, cultural, etc.) or an infinite diversity of objects, ${ }^{5}$ the history of the body is constantly exposed to criticism, incomplete for some but insufficiently theorized for others. ${ }^{6}$ In other words, it is always a symbolic history of the body, which

show that the split was permitted and anticipated within the notion of the king's two bodies itself. For an opposing view, see Louis Marin, Portrait of the King (Minneapolis: University of Minnesota Press, 1988), especially p. 14, and Jean-Marie Apostolidès, Le roi-machine. Spectacle et politique au temps de Louis XIV (Paris: Éd. de Minuit, 1981). These texts consider the ways that the unity of the two bodies was maintained in the early modern era, respectively highlighting procedures for exchange and mediation between them.

3. Marc Bloch, Feudal Society [1939], trans. L. A. Manyon (London: The Folio Society, 2012), 97. Lucien Febvre, Pour une histoire à part entière (Paris: Sevpen, 1962), $544-45$, called for the study of man in his concreteness, "living man, man in flesh and blood." The "body techniques" and "total man" of Marcel Mauss are also often invoked: see Mauss, Sociologie et anthropologie (1950; repr. Paris: Presses universitaires de France, 2003), especially pp. 368-69. Jan Bernhard Meister, for example, reduces the theme to the usage of insignia, and therefore to a question of propaganda and meaning. See Meister, "Corps et politique : l'exemple du corps du prince. Bilan historiographique," in "L'histoire du corps dans l'Antiquité. Bilan historiographique," ed. Florence Gherchanoc, special issue, Dialogues d'histoire ancienne, suppl. 14 (2015): 109-25, here p. 111.

4. It is difficult to imagine what kind of history of the body the aporetic thought and unfinished work of Merleau-Ponty might have authorized: see Merleau-Ponty, The Visible and the Invisible, trans. Alphonso Lingis (Evanston: Northwestern University Press, 1968). What historiographical translation, for example, might the problematic concepts of "intertwining," "chiasm," and "flesh" have received? For the rest, see Michel Foucault, The History of Sexuality, Volume I: An Introduction, trans. Robert Hurley (New York: Pantheon Books, 1978), 157, and his preface to Herculine Barbin: Being the Recently Discovered Memoirs of a Nineteenth-Century French Hermaphrodite, trans. Richard McDougall (New York: Vintage Books, 1980), xiii-xiv, which is followed by Oscar Panizza's 1893 essay, "A Scandal at the Convent."

5. Rafael Mandressi, "Le corps et l'histoire, de l'oubli aux représentations," in La tentation $d u$ corps. Corporéité et sciences sociales, ed. Dominique Memmi, Dominique Guillo, and Olivier Martin (Paris: Éd. de l'EhEss, 2009), 143-69, here p. 164.

6. Yannick Ripa, "L'histoire du corps, un puzzle inachevé," Revue historique 644 (2007): 887-98, review of Alain Corbin, Jean-Jacques Courtine, and Georges Vigarello, eds., Histoire du corps, 3 vols. (Paris: Éd. du Seuil, 2005-2006). The three moments sketched out here (totalization, representation, division) are juxtaposed in the majority of publications on the history of the body, where the ambitious projects of historical anthropology-particularly that of Mauss—are reduced to the bare essentials: totalization has only a distributive sense and the body is merely the summation of the signs it bears. 
proceeds by transposition and which aims to make the mute evidence of the flesh speak. The conversion of this flesh into semiology and of the body into a discursive system fits perfectly with these scholarly habits, and makes it clear just how entrenched they are. ${ }^{7}$

But such an approach is ill-suited in the case of antiquity. The seductive model of the king's two bodies, reduced to the separation between the real and the symbolic, has become something of a commonplace in discussions on power. Yet it is not operative for ancient Greece, where the practice of monarchy was accompanied by neither a figurative theory of power nor a generalized system of equivalence between image and person. ${ }^{8}$ Moreover, it would be difficult to argue for any sort of "acclimation" of the notion. Kantorowicz himself was aware of the phenomenon of "duplication" in antiquity, and even made it the subject of an unusual epilogue dedicated to safeguarding the specificity of the concept of the "two bodies."

In antiquity, the distinction between the two bodies was a possibility that came into being in a partial, disjointed manner, and which never became a stabilized duality. ${ }^{10}$ The body of the king was a compact unity where it was impossible to distinguish the real from the symbolic: Greek thought is in fact shot through by the topos of the naturally royal individual. This unicity is not an obstacle to thought, but rather the specific fact on which all reflection must be based if we are to truly understand the phenomenon. Put negatively, it fetishizes neither the natural nor the political body. The biological body as such is politicized only locally and according to precise circumstances, while the trappings of power have no value of their own and, alone, do not make a king. The first requires the second as its natural extension. The second derives its meaning from the first, whose properties it intensifies at the risk of being perceived as an artificial factor, compromising the political effectiveness it is meant to augment. The king, to use Plutarch's fine expression, is the one who has managed to bring together the body and the insignia of power. ${ }^{11}$

Discussing the latter, then, amounts to discussing the former, and it is this complex system of exchanges between the king, his body, and kingship-specific

7. See, for example, Claude Lévi-Strauss, Structural Anthropology, trans. Claire Jacobson and Brooke Grundfest Schoepf (New York: Basic Books, 1963), 198.

8 . Both supporters and critics of monarchy are caught up with the question of the conformation of the historical body to the glorious body, which is achieved through images and thus implies a belief in their power. See Louis Marin, Food for Thought, trans. Mette Hjort (Baltimore: Johns Hopkins University Press, 1989), 218 sq., particularly regarding William Makepeace Thackeray's caricature of the portrait of Louis XIV by Hyacinthe Rigaud. Outside this system of representations, it seems fruitless to export the categories of the real and symbolic and cut off the latter from its natural substrate, as this leads to the conclusion that it is impossible to know the king's "true" body-a verdict reached by François Queyrel, "Le corps du roi hellénistique," in Penser et représenter le corps dans l'Antiquité, ed. Francis Prost and Jerome Wilgaux (Rennes: Presses universitaires de Rennes, 2006), 361-76.

9. Kantorowicz, The King's Two Bodies, 497.

10. According to Roger Brock, Greek Political Imagery from Homer to Aristotle (London: Bloomsbury, 2013), 69-82, the idea of the political community as a body, in other words organicism, existed in ancient Greece, but in an incomplete manner.

11. Plutarch, Life of Demetrius 46.1. 
to the Hellenistic monarchies - that I seek to outline in the present article. If there can be no question about naively returning to the body itself, "the boundary stone where knowledge falters and stops, and where all discourse falters as well," 12 we can take a circuitous route and consider it not as a given but in terms of its effects. To put it another way, I want to explore the manner in which the king's body, once adorned in costume, affects a sovereignty where authority constantly stretches between transparency and obstruction, between sign and mask. I will do so by reading the texts almost naively, starting from the ways that the ancient Greeks themselves theorized power.

Before considering the Hellenistic period, it is necessary to turn first to Xenophon and his Cyropaedia, which offers the most complete exploration of the problems relating to the constitution of a Greek monarchy, and then to the manner in which Alexander the Great attempted to resolve, in practice, the same difficulties. Though they attempted many solutions, Alexander's successors never arrived at a stable compromise between the naturalization and the symbolization of royalty. A power which suffered from its incarnation, a sovereignty which continually let its founding principles slip away while desperately attempting to give them form: this, in a nutshell, was perhaps the fundamental problem of the Hellenistic monarchies.

\section{From Kingdom to Empire, From Cyrus to Alexander}

Turning to Xenophon is especially necessary as there are no sources from the Hellenistic period that treat the authority of kings: the mirrors of princes, those numerous peri basileias texts, are irrevocably lost. ${ }^{13}$ Nevertheless, the question of royalty had been discussed in Athens from the fourth century BCE, notably within Socratic circles. Among the texts which issued from these conversations, the reflections contained in the Cyropaedia anticipate the comportment of Hellenistic monarchs to such an extent that it enjoys a special status. ${ }^{14}$

\section{Extending and Symbolizing Authority}

Rather than viewing the Cyropaedia as a model of kingship-indeed, it is hard to believe that Alexander and his successors had read and reflected upon the writings of an Athenian, whatever his literary success-this "prophetic" convergence can be explained by a homology. Its author confronts in thought the problem that

12. Jacques Revel and Jean-Pierre Peter, "Le corps. L'homme malade et son histoire," in Faire de l'histoire, ed. Jacques Le Goff and Pierre Nora, vol. 3, Nouveaux objets (Paris: Gallimard, 1974), 169-91, here p. 185.

13. Oswyn Murray, "Philosophy and Monarchy in the Hellenistic World," in Jewish Perspectives on Hellenistic Rulers, ed. Tessa Rajak et al. (Berkeley: University of California Press, 2007), 13-28, nevertheless attempts to reconstruct their standard content. 
Alexander and his successors would later confront in reality: how to convert unstable political power derived from a dynamic of conquest into legitimate authority over a composite territory, or, depending upon whether we employ modern or ancient discourses, how to pass from power to legitimacy, to make charisma concrete, or

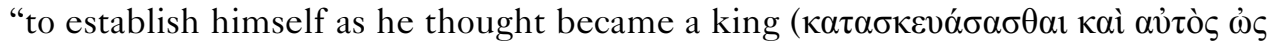

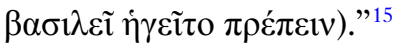

Indeed, Xenophon recounts that as soon as he settled in Babylon, Cyrus

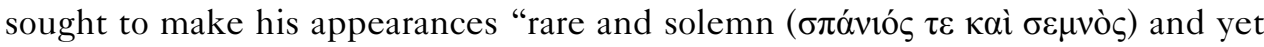

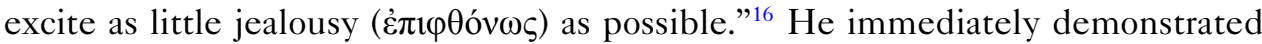
the degree to which the old form of authority, personal and direct, was no longer tenable. Having devised a curial system that made it possible to distinguish the rulers from the ruled (tous archontas tōn archomenōn diapherein), the Persian sovereign became, as Vincent Azoulay has shown, a "hidden king." Shutting himself away in the palace, Cyrus surrounded himself with eunuchs and bodyguards while building an administration designed to retain his grip on his empire. ${ }^{17}$ In the midst of these measures, he enacted vestimentary reforms designed to "cast a sort of spell" (katagoêteuein) on his subjects through spectacle:

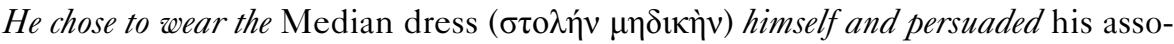

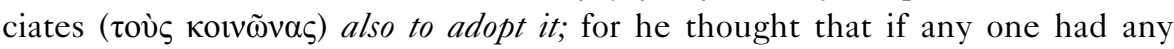
personal defect, that dress would help to conceal it, and that it made the wearer

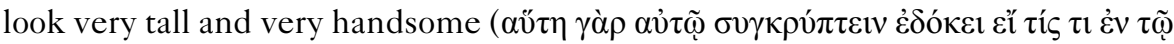

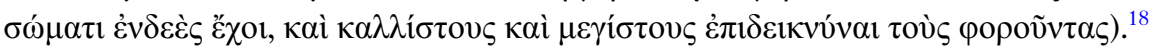

Cyrus and his companions also wore adjustable shoes in order to appear taller and used makeup to enhance their eyes. All refrained from spitting or blowing their noses, and never turned to watch any kind of spectacle, comporting themselves as men whom nothing could surprise (hōs ouden thaumazontes). In one sense, Cyrus returned to his childhood infatuation-born as he gazed in awe at his grandfatherand simply adopted wholesale the Median costumes he had encountered during his education..$^{19}$ However there are two reasons for not pushing this reading too far.

First, we should not reduce these vestments to masks in the straightforward sense, since the display (epideiknunai) of beauty and nobility was perfectly

15. Xenophon, Cyropaedia 7.5.37. On the meaning of prepein in this passage, see the remarks of Pierre Carlier, "L'idée de monarchie impériale dans la Cyropédie de Xénophon," Ktèma 3 (1978): 133-63.

16. Xenophon, Cyropaedia 7.5.37.

17. Vincent Azoulay, "The Medo-Persian Ceremonial: Xenophon, Cyrus and the King's Body," in Xenophon and his World, ed. Christopher Tuplin (Stuttgart: F. Steiner, 2004), 147-73. On the issue of the hidden king as it applies to the Persians, see Vivienne J. Gray, Xenophon's Mirror of Princes: Reading the Reflections (Oxford: Oxford University Press, 2011), 281-82. A description of the arrangement is given in Pseudo-Aristotle, De Mundo 6.5.398a.

18. Xenophon, Cyropaedia 8.1.40.

19. Xenophon, Cyropaedia 1.3.1-2. See the remarks of James Tatum, Xenophon's Imperial Fiction: On "The Education of Cyrus" (Princeton: Princeton University Press, 1989), 187. 
harmonized with their wearers' physical attributes. Cyrus himself was exceptionally handsome, and did not miss an opportunity to encourage his subordinates to exercise: "bodies ... that were once in good condition change and deteriorate as soon as the owners relax into idleness... Therefore, we dare not become careless nor give ourselves up to the enjoyment of the present moment." ${ }^{20}$ Thus, luxury was not meant as a substitute for bodies, but rather to intensify their presence and act as a sign of their virtue. Neither ersatz nor pretense, these vestments were the necessary corollary to a new type of sovereignty, one which privileged distance, secrecy, and rare appearances designed to impress its spectators. ${ }^{21}$

Second, these artifices were not intended for everyone. While splendor (semnotēs) became an issue of government policy, ${ }^{22}$ it also served to highlight the creation of a homogenous inner circle, whom Xenophon subsequently describes as members of a team (koinones) rather than as peers (homotimoi). Henceforth, hierarchy was defined through one's share in the secret of royal glory, and from this perspective the false contradiction between new and old ideas, between pomp and simplicity, resolved itself into a nuanced spectrum of distance and proximity. ${ }^{23}$ For the king did not present himself to his friends in all his finery, as Cyaxares had once appeared to Cyrus, or at least he could not claim to dupe them. What is more, this group acted as he did, with utmost self-control (enkrateia), and dressed in the same finery, likewise concealing their bodies from the populace-efforts ultimately aimed at the anonymous crowd that gathered around them during their public appearances. ${ }^{24}$

Incidentally, there is no need to detect any irony in Xenophon's reflections, which may have appeared outrageous to Athenian readers, ${ }^{25}$ since similar material is found in the work of a writer often considered a peaceful dreamer. In fact, Isocrates gave the same advice to a Cyprian tyrant:

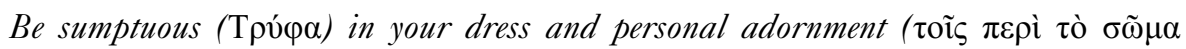

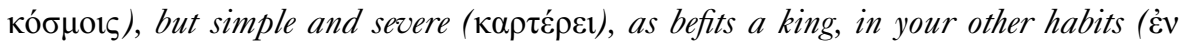

20. Xenophon, Cyropaedia 1.2.1 and 7.5.75-76 (for the citation); see also 8.1.38-39 (on hunting practices).

21. As soon as Cyrus rode out in full regalia, his subjects prostrated themselves before

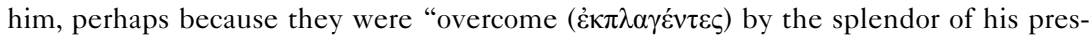
ence, or because Cyrus appeared so great and so goodly to look upon." Xenophon, Cyropaedia 8.3.14. Christopher Nadon, Xenophon's Prince: Republic and Empire in the Cyropaedia (Berkeley: University of California Press, 2001), 133-34, observes that there was no contradiction here between luxury and virtue, considering that Cyrus used ceremonial as a pedagogical device for the less discerning, and that it was, in fact, a functional necessity.

22. Xenophon, Cyropaedia 8.3.1: "for the magnificence ( $\dot{\eta} \sigma \varepsilon \mu v o ́ \tau \eta \varsigma)$ of his appearance in state seems to us to have been one of the arts that he devised to make his government

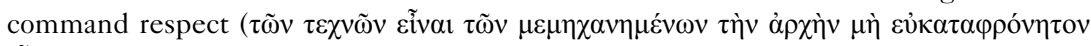
Eĩval)."

23. Xenophon, Oeconomicus 10.3-5; see Vincent Azoulay, Xénophon et les grâces du pouvoir. De la charis au charisme (Paris: Publications de la Sorbonne, 2004), 160-63.

24. Xenophon, Cyropaedia 8.3.1. 


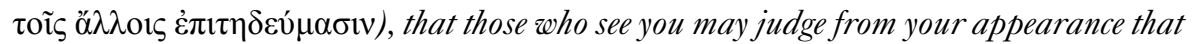
you are worthy of your office, and that those who are intimate with you may form the

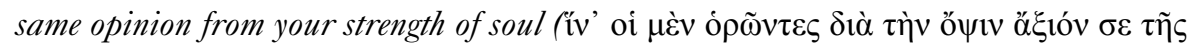

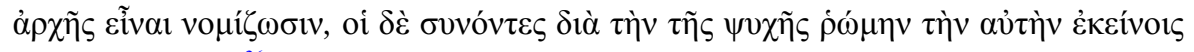
$\gamma \nu \omega ́ \mu \eta \nu$ है $\chi \omega \sigma ı))^{26}$

This advice seems to contradict the idea, broached elsewhere by Isocrates, that the Persians "because they are rich ... pamper their bodies; but because they are subject to one man's power ... keep their souls in a state of abject and cringing fear ( $\tau \dot{\alpha} \mu \dot{\varepsilon} v$

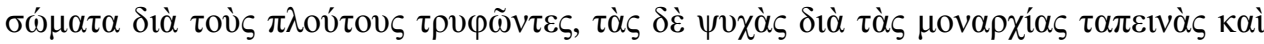
$\left.\pi \varepsilon \rho 1 \delta \varepsilon \varepsilon i \varsigma_{\zeta} \varepsilon \chi 0 \nu \tau \varepsilon \varsigma\right) . "{ }^{27}$ But the passage is no less authentic for all that, ${ }^{28}$ and perhaps represents a justification of a monarch who throughout his life "had shown great

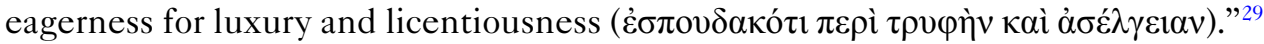
Even if we reverse the polarity, the political lesson remains: in order to establish oneself as a monarch, one needed to be "impressive."

It is true that the oppositions Isocrates posits between interior and exterior, between luxury (truphe $\bar{e}$ ) displayed on the body and self-control in matters of morality (here karteria, elsewhere sōphrosunē), between those who see (horōntes) and those who frequent (sunontes) the king, between appearance (opsis) and soul (psychēe, are more rigid than those of Xenophon. ${ }^{30}$ Nonetheless, however simple they might be, these alternatives throw a bright light on ancient sovereignty, taking us beyond moralism to reveal the importance of truphe in the acceptance of authority. ${ }^{31}$

26. Isocrates, To Nicocles (2) 32.

27. Isocrates, Panegyricus (4) 151. See also Isocrates, To Philip (5) 24.

28. For the debate over the authenticity of these passages, see Vincent Azoulay, "Le texte et ses interprétations: la politique isocratique de la réception," in Isocrate : entre jeu rhétorique et enjeux politiques, ed. Christian Bouchet and Pascale Giovannelli-Jouanna (Lyon: Centre d'étude et de recherche sur l'Occident romain, 2015), 107-24.

29. Anaximenes of Lampsacus quoted in Athenaeus of Naucratis, The Learned Banqueters 12.531e (Die Fragmente der griechischen Historiker [hereafter "FGrHist"] 72 F 18; trans. Brill's New Jacoby). See also Theopompus quoted in Athenaeus of Naucratis, The Learned Banqueters 12.531a-d (FGrHist $115 \mathrm{~F}$ 114). Given the degree to which the sources record

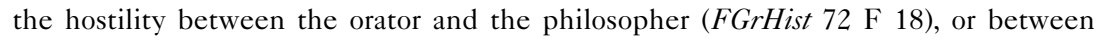
their disciples (FGrHist $72 \mathrm{~T} 12$ ), it is possible that Isocrates's discourse To Nicocles was intended to counter what Anaximenes had written.

30. See also Isocrates, Evagoras (9) 78: "For it has not escaped the notice of either me or anyone else that you, Nicocles, are the first and the only one of those who possess royal

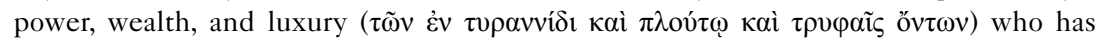
undertaken to pursue the study of philosophy ( tance of sōphrosunē for princes, see Isocrates, To Nicocles (2) 37. For a general approach to Isocrates as an author of mirrors of princes, see Pierre Hadot, "Fürstenspiegel," Reallexikon fur Antike und Christentum 8 (1970): 555-632, here pp. 574-76.

31. From this perspective, it may be that luxury was understood in a positive way in ancient Greece. An inscription shows the extent to which certain Hellenistic dynasts affirmed their truphē: Reinhold Merkelbach and Josef Stauber, eds., Steinepigramme aus dem griechischen Osten, vol. 4, Die Südkiiste Kleinasiens, Syrien und Palaestina (Munich: Saur, 2002), no. 17/19/03. On the different "virtues" of this particular dynast, see Matthias Haake, "Die patchwork-Repräsentation eines lykischen Dynasten: Apollonios, Sohn 


\section{Limiting the Risks of Pomp}

The life of Alexander the Great complicates this theoretical prognostication, refining the adoption of court ceremonial, while at the same time problematizing the relationship between the body and finery. Generally speaking, we encounter the blueprint drawn from the Cyropaedia, with Alexander alternating between the simple and approachable power he displayed on campaign and the more distant power on show after his proclamation as king of Asia in $330 \mathrm{BCE}$; between the king stripped of his clothes and the one who made known the full extent of his finery. ${ }^{32}$ It is also possible that he wished, like Cyrus, to develop a kind of uniform for his companions. ${ }^{33}$ Even if it was prompted by a precarious political situation and the threat from Bessus, the satrap of Bactria, this mutation was carefully calculated. ${ }^{34}$ Nevertheless, contrary to what one might observe in imperial fictions, Alexander did not adopt truphe as a whole but varied both its components and its temporality.

First of all, he was extremely selective in the composition of his new costume, avoiding Median elements in favor of Persian ones, the latter being judged less ornate and theatrical (exalla kai tragika) than the former. Indeed, he "used to wear garments in a mixture of the Persian and Macedonian style." ${ }^{35}$ This nuanced

des Hellaphilos, und das Grab vom Asartas Tepesi," in Vom Euphrat bis zum Bosporus. Kleinasien in der Antike, ed. Engelbert Winter (Bonn: Habelt, 2012), 277-96.

32. On sweat and nudity, see Quintus Curtius, History of Alexander 3.5.2, where they are interpreted as political techniques. This dimension is absent from the other sources, which above all stress the role of Alexander's physician, Philip of Acarnania: Arrian, Anabasis 2.4.7-11; Plutarch, Life of Alexander 19; Justin, Epitome of the Philippic History of Pompeius Trogus 11.8.6; Diodorus Siculus, The Library of History 17.31; FGrHist 148 F 44, col. 1; Valerius Maximus, Memorable Doings and Sayings 3.8 ext. 6; Seneca, De Ira 2.23.2. Later, however, Themistius used the anecdote to urge Constantine to build a

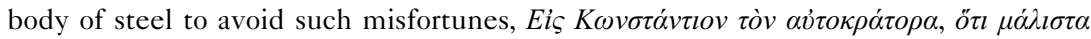

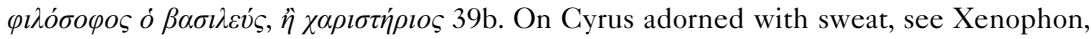
Cyropaedia 2.4.6, and the remarks of Bodil Due, The Cyropaedia: Xenophon's Aims and Methods (Aarhus: Aarhus University Press, 1989), 108.

33. Quintus Curtius, History of Alexander 6.6.7; Diodorus Siculus, The Library of History 17.77.5; Justin, Epitome 12.3.9. According to Athenaeus of Naucratis, The Learned Banqueters 12.539f (FGrHist $81 \mathrm{~F} 41$ ), only five hundred of Alexander's friends had the right to wear purple clothing. Others disagree; see Plutarch, Life of Alexander 47.9, and Life of Eumenes 6.3.

34. Albert B. Bosworth, "Alexander and the Iranians," Journal of Hellenic Studies 100 (1980): 1-21, here pp. 5-6. On the costume's composition and provenance, see Ernst A. Fredricksmeyer, "The Origin of Alexander's Royal Insignia," Transactions and Proceedings of the American Philological Association 127 (1997): 97-109, which argues for the Dionysian origins of the diadem. For an opposing view, see Andrew W. Collins, "The Royal Costume and Insignia of Alexander the Great," American Journal of Philology 133, no. 3 (2012): 371-402. All evidence pertaining to these questions is inventoried by Andrew F. Stewart, Faces of Power: Alexander's Image and Hellenistic Politics (Berkeley: University of California Press, 1993), 350-57. 
vestimentary strategy allowed him to preserve all the important elements of traditional Macedonian costume, such as the kausia, the kreppides, and the chlamys. Conversely, the elements borrowed from the Persians, most crucially the belt, brought to mind the imagery of the warrior king without upending the GrecoMacedonian imaginary. ${ }^{36}$ What is more, these changes were introduced gradually, first before the barbarians, then with his closest friends in his home, then in public, when he was on horseback or giving audiences. ${ }^{37}$

Attentive to the fit between his clothing and the population, Alexander was also attentive to the occasion. Indeed, Ephippus of Olynthus relates that he wore sacred garments (hieras esthêtas) to banquets:

Sometimes he would wear the purple robe, and cloven sandals, and horns of Ammon, as if he had been the god; and sometimes he would imitate Artemis, whose dress he often wore while driving in his chariot; having on also a Persian robe, but displaying above his shoulders the bow and javelin of the goddess. Sometimes also he would appear in the guise of Hermes.... And when he was in private with his friends he wore the sandals of Hermes, and the petasus [winged hat] on his head, and held the caduceus [herald's staff] in his hand. Often also he wore a lion's skin, and carried a club, like Herakles. ${ }^{38}$

It is difficult to extract a kernel of truth from this heterogeneous and controversial catalogue. The first costume seems to refer to the theme of Alexander's divinization, featured on the coinage of the Diadochi and of Lysimachus in particular. ${ }^{39}$ Ephippus perhaps misunderstood the second costume which, with its Persian robe, its bow, and its lance, strongly resembled the military attire of an Achaemenid king. ${ }^{40}$ As for the Hermes costume Alexander is said to have worn at parties (sunousia), Kevin Trehuedic suggests that it was a national costume with the addition of batons, in the manner of scepters. ${ }^{41}$ It may have been a costume dedicated to messages and communication, and thus ultimately for formal hearings or audiences. Ephippus thus depicts the king as a god, a warrior, and a judge, assuming that Alexander had an appropriate costume available, if not for each of these roles, at least for each occasion - as if time and costume needed to be subtly linked together. $^{42}$

36. Kevin Trehuedic, "Insignes et marqueurs du pouvoir hellénistique. Traditions et stratégies dans la royauté d'Alexandre et dans l'Orient hellénisé" (PhD diss., Université Paris-Est, 2008), 104-5.

37. Plutarch, Life of Alexander 45.2.

38. Ephippus of Olynthus quoted in Athenaeus of Naucratis, The Learned Banqueters $12.537 \mathrm{e}-538 \mathrm{~b}$ (FGrHist $126 \mathrm{~F} 5$; trans. Brill's New Jacoby).

39. Collins, "The Royal Costume and Insignia," 377. The link with Heracles can be explained in the same way.

40. A full analysis of this passage can be found in Trehuedic, "Insignes et marqueurs du pouvoir hellénistique," 113-14.

41. On the scepter during Alexander's reign, see ibid., 114 and 156 sq. Some statues perhaps represented the king in majesty, as he would have appeared during audiences: see Brigitte Fröhlich, Die statuarische Darstellung der hellenistischen Herrscher (Hamburg: Verlag Dr. Kovač, 1998), cat. no. 42.

42. The use of such costumes is not, however, attested elsewhere and does not seem particularly credible. 
Yet even this limited use of oriental pomp was shocking, especially the adoption of the belt, which for the Persians symbolized loyalty, but which the Macedonians saw as a sign of servitude. The resulting criticisms of Alexander thus mobilized the commonplace of the lulling effects of luxury. Faced with this inversion, where finery contaminated the body and corrupted its natural vigor, the ancient historiography seems to have adopted two strategies aimed at separating the natural from the symbolic. We should see this as a kind of defense or apology, a way of safeguarding the body of the king by setting it apart and preserving its primacy.

On the one hand, Alexander could be depicted as a king in perfect control of himself, a philosopher who scolded those friends who gave themselves over to debauchery. Aelian the Sophist describes the sumptuous finery of the hetairoi, blaming the Argead who "spoiled ( $\delta 1 \varepsilon \dot{\theta} \theta 0 \pi \tau \varepsilon)$ his friends by allowing them excessive luxury ( $\tau \rho v \varphi \tilde{\alpha} v) .{ }^{33}$ But Plutarch, who was familiar with the same anecdote, gives a slightly different version of it. Not only did Alexander see "that his favorites had grown altogether luxurious ( $\pi \alpha v \tau \alpha \dot{\alpha} \pi \alpha \sigma \mathrm{v} \dot{\varepsilon} \kappa \tau \varepsilon \tau \rho v \varphi \eta \kappa o ́ \tau \alpha \varsigma)$ and were

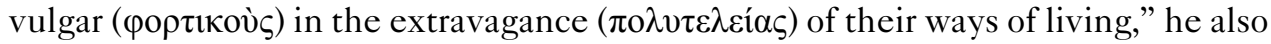

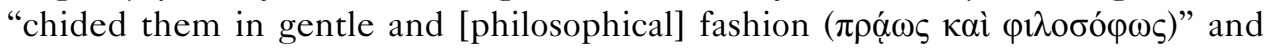
accordingly "exerted himself yet more strenuously in military and hunting expeditions." ${ }^{44}$ Of course, the motif of the philosopher king is a later invention, a product of the dispute between different philosophical schools. ${ }^{45}$ But the virtues attributed to him here are largely conventional and the portrait they sketch out in all likelihood goes back to the time of the Conqueror himself, when these affirmations might have served to counter accusations made against his luxury (truphēe). ${ }^{46}$ The insistence on exertion (ponos) and exercise (askēsis) in particular bring us back to themes explored, if not in the Argead's own propaganda, at least within his immediate entourage. ${ }^{47}$ Here as elsewhere, the true king is first of all master of himself, and his continence the proof that he can govern others. The implication is that Alexander, despite the luxury, would have kept his former habits-just like

43. Aelian, Historical Miscellany 9.9.3.

44. Plutarch, Life of Alexander 40.1-4 (translation modified); see also ibid., 41.1.

45. Gabriele Giannantoni, "Cinici e stoici su Alessandro Magno," in I filosofi e il potere nella società e nella cultura antiche, ed. Giovanni Casertano (Naples: Guida, 1988), 75-87. 46. Ephippus and Agatharchides (FGrHist $126 \mathrm{~F} 4$ and $86 \mathrm{~F}$ 2), for example, accuse Alexander of having given in to oriental luxury. For other references, see Rainer Bernhardt, Luxuskritik und Aufwandsbeschränkungen in der griechischen Welt (Stuttgart: F. Steiner, 2003), 242.

47. On the king's exertions, see Demosthenes, Letters 1.13 , as well as the commentary in Elias Koulakiotis, Genese und Metamorphosen des Alexandermythos im Spiegel der griechischen nichthistoriographischen Überlieferung bis zum 3. Jh. n. Chr (Constance: Universitätsverlag Konstanz, 2006), 52-53; Plutarch treats the same theme, describing Alexander as a philosopher king. Regarding Alexander's entourage, the embassy of Onesicritus, a Cynic philosopher, to the Indian gymnosophists comes to mind: see Strabo, Geography 14.1.64-65 (FGrHist 134 F 17). It is hard to distinguish what belongs to Indian thought and what to Greek themes in these passages: Paul Pédech, Historiens compagnons d'Alexandre. Callisthène, Onésicrite, Néarque, Ptolémée, Aristobule (Paris: Les Belles Lettres, 1984), 109; Ragnar Höistad, Cynic Hero and Cynic King: Studies in the Cynic Conception of Man (Uppsala: s.n., 1948), 43 sq. and 135 sq. 
Xenophon's Cyrus, who dined only after he had worked up a sweat and whose finery was merely a postiche, the spectacular extension of an already perfect and completely disciplined body.

On the other hand, in the first century CE a Roman such as Quintus Curtius could not pass over the opportunity to develop the theme of the conquered conqueror. In his view, Alexander "used to say that he was wearing the spoils of the Persians (spolia Persarum); but with them he had assumed also their customs, and insolence of spirit accompanied the magnificence of his attire (superbiamque habitus animi insolentia sequebatur)." 48 Unsurprisingly, the Latin author uses all the rhetorical tropes at his disposal to expound the theme of pride (superbia), a perfect fit for the structure of his Histories, whose last five books seek to describe a king overcome by licentiousness. ${ }^{49}$ Yet the idea of wearing this costume as a war trophy had perhaps been formulated by the king himself, since it finds a parallel in the theme of the "spear-won land." ${ }^{50}$ In this sense, by seeming to deny all intrinsic meaning to Persian clothing-valued only in so far as it symbolized the grandeur of his defeated opponents-Alexander shattered and reconfigured the harmonious continuity between the body and its finery. Ironically, Persian attire came to enhance the Conqueror's prestige by playing on a commonplace developed during the Greco-Persian Wars, and exploited early on by Alexander himself. ${ }^{51}$

We cannot escape the royal body's essential oneness. Its single nature permitted no strict separation between the real and symbolic, but rather entailed a continuous process of interaction, as one aspect conquered the other, either victorious over luxury or defeated by it. Garments might be worn as postiches or trophies, but they were always seen as extensions of a body which, through its intrinsic qualities, was the unique source of their meaning. Provided that he was master of himself, Alexander could allow for every extravagance, while as master of others he took possession of their luxury, turning it into a symbol of his superiority. No doubt one must insist on the fragility of this regime: his garments might-in accordance with the common conception of a naturally royal appearance-appear as prostheses for an already glorious body, but the process could always reverse

48. Quintus Curtius, History of Alexander 6.6.5.

49. On the construction of this account, see Elizabeth Baynham, Alexander the Great: The Unique History of Quintus Curtius (Ann Arbor: University of Michigan Press, 1998), 42.

50. Robin Lane Fox, "Alexander the Great: 'Last of the Achaemenids'?" in Persian Responses: Political and Cultural Interaction with(in) the Achaemenid Empire, ed. Christopher Tuplin (Swansea: Classical Press of Wales, 2007), 267-311, here pp. 278-79.

51. Plutarch, Life of Alexander 20.8: "And when he saw the basins and pitchers and tubs and caskets, all of gold ... he turned his eyes upon his companions and said: 'This, as it would seem, is to be a king." A very similar moment of offbeat humor is already present in Herodotus when the Greeks capture the enemy king's tent during the Greco-Persian Wars. Alexander's attitude, however, is one of incomprehension, and parallels his reaction at Susa, when he sat on a throne too high for him (Diodorus Siculus, The Library of History 17.66.3-7; Quintus Curtius, History of Alexander 5.2.11-13) during a ceremony whose stakes were nevertheless important (Arrian, Anabasis 7.24.3). 
itself, the clothing coming to taint the body. In either case, it was impossible to rigorously separate luxury from the king's body: the two were caught in a veritable struggle.

Clothing had no efficacy of its own. On the contrary, the centrality of the royal body was revealed at the Argead's death, when his cadaver was displayed with a simple purple chlamys and his military tunic. ${ }^{52}$ Likewise, when the body was transported it was covered only with a purple cloak in the Macedonian fashion. ${ }^{53}$ No trace, then, of Alexander's new costume, whereas the royal body (basilikon sōma) had been embalmed for the harsh journey. And when Ptolemy I Soter diverted the mummy, he did so by abandoning the signs of glory that surrounded it to the desert, even though they had fascinated onlookers. ${ }^{54}$ Finally, when Eumenes later wished to secure his position by holding court around the empty throne of Alexander, he was careful to display diverse insignia of the sovereign, but no clothing $^{55}$ : royalty, one could say, had never been objectified, and never existed autonomously in the king's costume.

Luxury therefore played an ambivalent role. It certainly served to enhance an already glorious body before the masses and in new conditions: an extremely vast territory, the retreat of the sovereign into his palace, and striking public appearances. But it also had to be rigorously separated from the natural body whenever the authority of the king needed to be reaffirmed against the danger of appearing softened and feminized through truphe. . One cannot overstate the tactical character of such a move, which emerged in a context of crisis and was intended to safeguard the sovereign's authority. The natural appeared, as it were, only intermittently and by substraction. It was always informed by the exigencies of authority.

\section{The Interplay of Real and Symbolic during the Hellenistic Period}

The Diadochi inherited the same paradox: luxury, which glorified power, also undermined its foundations. However, two inflections can be observed during this period. A series of interchanges and crossovers opened up between the natural body and bodily symbolism, while a freer interplay between pomp and simplicity, between

52. Metz Epitome 113.

53. Diodorus Siculus, The Library of History 18.26.4.

54. The passage in Aelian's Historical Miscellany 12.64, comes to mind here, which contrasts an ornate imitation of Alexander's body with the real corpse shorn of finery. Aelian was the sole author, however, to emphasize this theme: see Diodorus Siculus, The Library of History 18.28.3; Arrian, FGrHist 156 F 9; Quintus Curtius, History of Alexander 10.10.20; Pausanias, Description of Greece 1.6.3; Strabo, Geography 17.1.8.794; Liber de morte testamentoque Alexandri 119; Pseudo-Callisthenes, Alexander Romance 3.34.4-6. 
distance and proximity, came into being. The first of these transformations arose in large part from contact with indigenous traditions; the second from the confrontation with Rome. In both cases, luxury became the norm.

\title{
Imitating Alexander
}

At the end of a period of experimentation whose central questions were bound up with the imitatio Alexandri, Alexander came to represent a horizon of expectations. ${ }^{56}$ But, when it came to his body, was one to imitate the taste for luxury or the natural appearance ${ }^{57}$ In his Life of Demetrius, Plutarch compares Pyrrhus and Demetrius Poliorcetes:

\begin{abstract}
Among the Macedonians ... many of them were moved to say that in [Pyrrhus] alone of all the kings could they see an image of the great Alexander's daring ( $\varepsilon i \delta \omega \lambda o v$ Ėvo

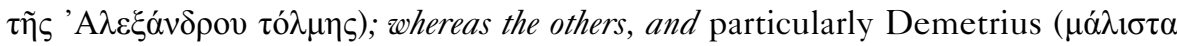
$\Delta \eta \mu \eta ́ \tau \rho ı \varsigma)$, did but assume Alexander's majesty and pomp, like actors on a stage

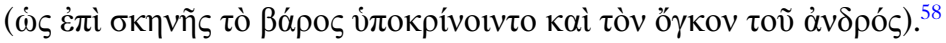

While Pyrrhus kept his appearance simple, "there was ... much of the theatrical about Demetrius," who wore a double-mitered hat, gold-embroidered purple robes, purple shoes stitched with gold, and a cloak woven with images of the universe and the celestial bodies. ${ }^{59}$ These famous passages have been interpreted from two

56. On the diadem, see Matthias Haake, "Diadem und basileus. Überlegungen zu einer Insignie und einem Titel in hellenistischer Zeit," in Das Diadem der hellenistischen Herrscher. Übernahme, Transformation oder Neuschöpfung eines Herrschaftszeichens? ed. Achim Lichtenberger et al. (Bonn: Habelt, 2012), 293-313. Haake shows the extent to which Alexander used this object in an informal way. It was the Diadochi who, through devotion or imitation, made it an emblem of power.

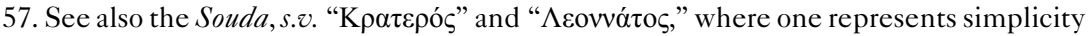
and the other luxury. Needless to say, this does not mean that the theme of the imitatio Alexandri was limited to the first few decades following Alexander's death. In fact, it was a possibility that was always present during the Hellenistic period, and which reappeared in the context of the Hellenization of the Far East or-in the case of Mithridates, for example-the struggle against Rome. Nevertheless, and even if certain Romans used it as a propaganda tool, it seems to me that this theme only posed a problem at the beginning of the Hellenistic period, when all the monarchs were competing over its appropriation. From the perspective of political history, see Claudia Bohm, Imitatio Alexandri im Hellenismus. Untersuchungen zum politischen Nachwirken Alexanders des Grossen in hoch- und späthellenistischen Monarchien (Munich: Tuduv, 1989).

58. Plutarch, Life of Demetrius 41.3-4.

59. Duris of Samos quoted in Athenaeus of Naucratis, The Learned Banqueters $12.535 \mathrm{f}$ (FGrHist 76 F 14) and Plutarch, Life of Demetrius 41.4-5, citation at 41.5. The Boeotian says that the chlamys was only hemmiphues, "half-finished," but he seems to have misunderstood a term of art: see Marie-Thérèse Picard-Schmitter, "Sur la chlamyde de Démétrios Poliorcétès," Revue archéologique 46 (1955): 17-26. 
angles. Some scholars have remarked upon the degree to which the Life of Demetrius is full of the reversals of fortune characteristic of tragedy. ${ }^{60}$ Others have read it as a further sign of the "theatricality" pervading the controlled appearances of the political "actors" of the Hellenistic period. ${ }^{1}$ But neither approach grasps the political problem posed by this costume and the new power that it simultaneously instituted and signified.

Because they were made from luxurious materials and rich fabrics, Demetrius's garments undoubtedly enabled him to stand out from all the aristocrats, not least the other Diadochi. Nec pluribus impar could equally have been the motto of this other "Sun-King" 62 "like no other," but this would not do justice to the complexity of the royal costume. As a whole, Demetrius's accoutrements were no different from those of any other Hellenistic king and recalled the traditional dress of the Macedonians. ${ }^{63}$ But each of the elements seems specific. The headband was knotted around the cap (kausia), in an entirely traditional way. But instead of a diadem, Demetrius wore multicolored golden fabric, recalling the purple and white headdress of the Persian king. ${ }^{64}$ The length of the pennants, which came to rest on his back, continued Dionysian or agonistic iconography. ${ }^{65}$ He wore ankle boots or gaiters (embatai or embades depending on whether one reads Duris of Samos or Plutarch), whose main function was to stand in opposition to the military

60. Plutarch, Life of Demetrius 18.1, 25.9, 28.1, 34.4, 41.5-6, 44.9, and 53.1. See in general Phillip De Lacy, "Biography and Tragedy in Plutarch," American Journal of Philology 73, no. 2 (1952): 159-71, notably 168 sq.; Waldo E. Sweet, "Sources of Plutarch's Demetrius," Classical Weekly 44, no. 12 (1951): 177-81, here pp. 180-81; Attilio Mastrocinque, "Demetrios tragodoumenos (propaganda e letteratura al tempo di Demetrio Poliorcete)," Athenaeum 57 (1979): 260-76; and, more recently, Luigi Santi Amantini, "La 'tragedia' di Demetrio Poliorcete, re senza regno, e la terminologia teatrale nelle biografie di Plutarco," in Le maschere del potere. Leadership e culto della personalità nelle relazioni fra gli Stati dall'antichità al mondo contemporaneo, ed. Francesca Gazzano and Luigi Santi Amantini (Rome: L'Erma di Bretschneider, 2013), 57-74.

61. Angelos Chaniotis, "Theatricality beyond the Theater: Staging Public Life in the Hellenistic World," Pallas. Reoue d'études antiques 47 (1997): 219-59, especially pp. 244-45 on Demetrius.

62. On the costume's celestial aspect, see Lara O'Sullivan, “'Le Roi Soleil': Demetrius Poliorcetes and the Dawn of the Sun-King," Antichthon 42 (2008): 78-99. Curiously, O'Sullivan does not mention how often the theme of the Apollonian king is found in Roman discourse on tyrants.

63. Chryssoula Saatsoglou-Paliadeli, "Aspects of Ancient Macedonian Costume," Journal of Hellenic Studies 113 (1993): 122-47.

64. Trehuedic, "Insignes et marqueurs du pouvoir hellénistique," 30.

65. Duris of Samos quoted in Athenaeus of Naucratis, The Learned Banqueters 12.535e536a (FGrHist 76 F 14; trans. Brill's New Jacoby): "His head-dress was studded with gold, and it held fast his felt hat, made of genuine purple dye, and the fringed edges of its material went down to his back." See Dieter Salzmann, "Anmerkungen zur Typologie des hellenistischen Königsdiadems und zu anderen herrscherlichen Kopfbinden," in Lichtenberger et al., Das Diadem der hellenistischen Herrscher, 337-83, here p. 350, nos. 44-45 (for comparisons), and p. 352, nos. 52-53 (for the argument). 
footwear (krēpides) worn by his rivals. Likewise, his cloak (chlamys or perhaps chlanis) could refer just as well to the world of war as to that of tragedy, ${ }^{66}$ whereas the celestial motif seems to owe much to the Athenian context. ${ }^{67}$

The sovereign thus wore a costume that was classic in its arrangement (kausia, diadèmatophoros, chlamydes, krēpides) but exorbitant in its elements. The ensemble pointed towards Macedon, while each of its parts gestured in a different direction: the East, the world of the Greek cities, and ultimately the theater. The symbolism of the new luster that Demetrius wished to give the national costume escapes us. Yet the sequence into which this figure was inserted by Duris and Plutarchboth of whom compare him to Alexander the Great-remains. The king was, so to speak, of Alexander's school. Like him, he put together a mixed costume by blending elements of diverse provenance. Like both Alexander and Xenophon's Cyrus, the luxury Demetrius displayed on his body served to establish and stabilize his authority by introducing a distance between himself and the everyday.

In addition to Demetrius's "displays," "his luxurious ways of living were also offensive [to the Macedonians], and above all else the difficulty of getting access

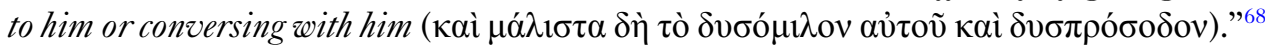
This inaccessibility was not simply the side effect of an excess of decorum, but a direct reflection of the sovereign's will. Indeed, one day he went out in simpler, more popular dress (dèmotikōteron) in order to collect the grievances of his subjects. But instead of treating them individually and rendering justice in minor cases, he tossed the petitions into the Axius River. ${ }^{69}$ This was too much for the Macedonians, who considered themselves victims of oppression (hybrizesthai dokountas). Yet this tendency was anticipated from the beginning of Plutarch's account:

Now, [adopting the title of king] did not mean the addition of a name or a change of fashion ( $\sigma \chi \eta \mu \alpha \tau o \varsigma)$ merely, but it stirred the spirits of the[se] men, lifted their

66. In his edition of Plutarch's Lives, Karl Sintenis suggested reading chlanis rather than chlamys in the Life of Demetrius 41.4, that is to say, the light mantel worn by men and women on stage: Sintenis, ed. Plutarchi, Vitae parallelae, vol. 4 (Leipzig: Teubner, 1875), 333. The hypothesis is taken up by Judith Mossman, "Dressed for Success? Clothing in Plutarch's Demetrius," in Fame and Infamy: Essays for Christopher Pelling on Characterization in Greek and Roman Biography and Historiography, ed. Rhiannon Ash, Judith Mossman, and Frances B. Titchener (Oxford: Oxford University Press, 2015), 149-61, here pp. 155-56. 67. O’Sullivan, “Le Roi Soleil,"” notably pp. 84-85 regarding Demetrius of Phalerum, Poliorcetes's predecessor. Mastrocinque, "Demetrios tragodoumenos," 270, argues that this costume had been made for Demetrius's return to Athens in 294 BCE. For a critical view, see Franca Landucci Gattinoni, Duride di Samo (Rome: L'Erma di Bretschneider, 1997), 130, n. 228.

68. Plutarch, Life of Demetrius 42.1 (my emphasis).

69. This is the sense of the anecdote recounted by Plutarch, Life of Demetrius 42.3, in which an old woman overwhelmed Demetrius with demands. Seeing his reluctance to listen to her, she rebuked him by shouting "then don't be king (Mì $\beta \alpha \sigma i ́ \lambda \varepsilon v \varepsilon)$ !" The commonplace is also applied to several other kings: see Plutarch, Sayings of Kings and Commanders 216a-b; Cassius Dio, Roman History 69.6; Stobaeus, Anthologium, ed. Otto Hense (Berlin: Weidmann, 1894), 3.13.48. 


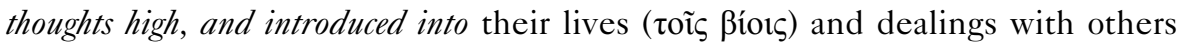

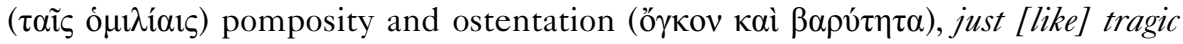
actors. ... Consequently, they became harsher in their judicial decisions ( $\pi \varepsilon \rho \grave{i}$ iòs

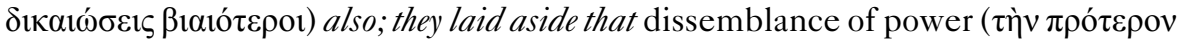

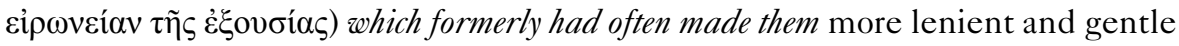

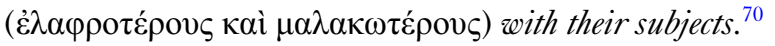

The "tragic" character of Demetrius should not be reduced to a problem of narratology or a change in political culture. It referred, first of all, to a shift in the exercise of power. In his appearance as well as his government, Demetrius continued Alexander's strategy. He adopted a mixed costume, refused to treat directly with the people, rarely appeared in public, and added trimmings even more magnificent than those of the Conqueror to a body already naturally royal. ${ }^{71}$ It is true that he met an unfortunate end, but in his excess, if Plutarch is to be believed, he came to define the horizon of expectations for the Hellenistic period. From now on, court ceremonial was universally accepted and luxury covered the body.

Nevertheless, up until the 280s BCE, matters were not fixed. Pyrrhus, at least, claimed to embody another type of royalty equally rooted in the imitatio Alexandri. According to Plutarch, he physically resembled Alexander: "For they likened his aspect and his swiftness and all his motions to those of the great Alexander

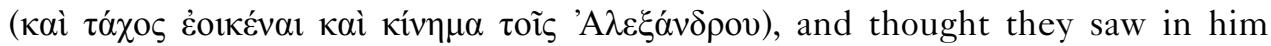
shadows, as it were, and imitations ( $\tau \imath \alpha_{\varsigma}$ ó $\left.\rho \tilde{\alpha} \sigma \theta \alpha \iota \kappa \alpha i ̀ \mu \eta \eta ́ \mu \alpha \tau \alpha\right)$ of that leader's impetuosity and might in conflicts." "In fact, the Epirite may well have presented himself as a new Alexander, as the "baroque" strand running through his iconography attests, by taking advantage of the ignorance of his soldiers who knew the Conqueror only through his portraits. ${ }^{73}$ All this would seem to suggest that up to the death of Pyrrhus we can trace a struggle between the true heirs and the imposters, between those who naturally resembled Alexander and all those who took from him only the taste for oriental luxury. Yet this opposition is too simplistic, and masks the back-and-forth which existed between the two dimensions.

Indeed, it is hard to see what distinguished Pyrrhus from the other successors who, through their gait or their facial expressions, yielded to this strange mimetism of power which elsewhere marked out the flatterer (kolax). They all mimicked several precise characteristics: they shaved their beards, inclined their

70. Plutarch, Life of Demetrius 18.3. The same idea is found in Polybius, Histories 6.7.7: "They gave way to their appetites owing to this superabundance, and came to think that the rulers must be distinguished from their subjects by a peculiar dress, that there should be a peculiar luxury and variety in the dressing and serving of their viands, and that they should meet with no denial in the pursuit of their amours, however lawless."

71. Plutarch, Life of Demetrius 2.2.

72. Plutarch, Life of Pyrrhus 8.1.

73. On the style of portraits of Pyrrhus, see Blanche R. Brown, Royal Portraits in Sculpture and Coins: Pyrrhos and the Successors of Alexander the Great (New York: Peter Lang, 1995), notably pp. 11-20 on the style of the Epirite's contemporaries. On Pyrrhus's propaganda, see Paul Goukowsky, Essai sur les origines du mythe d'Alexandre, vol. 1, Les origines politiques (Nancy: Université de Nancy II, 1978), 117. 
necks, adopted Alexander's manner of speaking, and so on. The multiplication of portraits as well as their reliance on stereotypes undoubtedly played a major role in the process whereby Alexander's body and physiological characteristics escaped his physical identity to become, in the absence of a living referent, a generic framework transmitted across the centuries as a sign of sovereignty. ${ }^{74}$

\section{Bodily Performances}

Concurrent with this transformation of a historical body into an archetype limited to a single body and a few particular traits, a naturalization of court ceremonial was underway. Plutarch's portrait of Demetrius was effectively still a Janus-like figure with two faces, sometimes plunging into action, sometimes into luxury, in any case absorbed in his activity: a simple king while at war, Demetrius became sophisticated at court. But other monarchs made luxury a regular feature of their existence, to the point that it was imprinted on their physical bodies, presented to the gaze of observers. Hence the aptly named Ptolemy VIII Euergetes II, known as Physcon (the Potbellied):

On account of his luxurious lifestyle his body was corrupted by fatness and by the size of his stomach, which as a matter of fact one could scarcely get one's arms round; when he went out in public, he covered it by dressing in a tunic which reached his feet and whose sleeves reached his wrists. But he never walked in public, except for Scipio (dia Skipiōna). ${ }^{75}$

Justin is even more explicit:

He emphasized his deformity by the excessive fineness of his transparent garb, as if taking pride in showing off what any decent person would make every possible effort to hide. ${ }^{76}$

74. See Plutarch, How to Tell a Flatterer from a Friend 53c sq., on the tendency of flatterers to imitate those with whom they wish to curry favor. The odd look and inclination of the neck have been attributed to a hypothetical case of Brown's syndrome: John Lascaratos and Alexander Damanakis, "Ocular Torticollis: A New Explanation for the Abnormal Head-Posture of Alexander the Great," The Lancet 347 (1996): 521-23; Alan E. Wardman, "Description of Personal Appearance in Plutarch and Suetonius: The Use of Statues as Evidence," Classical Quarterly 17, no. 2 (1967): 414-20. Both Stewart, Faces of Power, and Tonio Hölscher, Herrschaft und Lebensalter. Alexander der Grosse: Politisches Image und anthropologisches Modell (Basel: Schwabe, 2009), 31, n. 34, argue that the Diadochi imitated Alexander himself, whom they had known in person, rather than his statues. The argument does not hold for the second generation of Diadochi, born far from the centers of power (Demetrius Poliorcetes) or after Alexander's death (Pyrrhus). Besides, it is doubtful that the people to whom these images were addressed remembered the monarch's exact appearance thirty years after the conquests.

75. Posidonius quoted in Athenaeus of Naucratis, The Learned Banqueters $12.549 \mathrm{~d}-\mathrm{e}$ (FGrHist 87 F 6; trans. Brill's New Jacoby).

76. Justin, Epitome 38.8.10-11. This translation is based on the French version given in Heinz Heinen, "Aspects et problèmes de la monarchie ptolémaïque," Ktèma 3 (1978): 177-99, here p. 190. 
The author of this anecdote, Posidonius, never missed an occasion to ridicule these effeminate kings, too fat to take action and fight, yet always ready to dance, drink, and eat. ${ }^{77}$ But beyond the specific interest an austere thinker took in ill-formed bodies, the anecdote reveals more generally a Roman error or misunderstanding: the Lagids had in fact raised truphe to the rank of a royal philosophy for ruling the indigenous people, used as a symbol for prosperity. ${ }^{78}$ This double distortion perhaps reveals (but also exacerbates) a change in the public presentation of the sovereign body. On his coins and statues, Ptolemy appeared chubby, his lips and neck fleshy and plump-characteristics that continued to be depicted, to varying degrees, in portraits of his two successors. ${ }^{79}$ More broadly, his portraits fit into that series of fat and fleshy kings that appeared in Egypt between 180 and $160 \mathrm{BCE}$, and that other dynasties adopted as a model, each incorporating truphe in turn. ${ }^{80}$

Nevertheless, Ptolemy's epiphanic costume took people by surprise because it resembled a dress (Athenaeus of Naucratis) or because it highlighted the flesh (Justin). Even if it was a question of imitating the sensual Dionysos, having abandoned warfare, as Ptolemy II had already done in a famous procession, Ptolemy VIII's comportment remained relatively unusual. ${ }^{81}$ In his desire to show his body almost without mediation, or to do away with the vestimentary mask,

77. On Physcon and his son, Ptolemy X Alexander I, see Diodorus Siculus, The Library of History 33.23, and Athenaeus of Naucratis, The Learned Banqueters 12.550a-b (FGrHist 87 F 26), respectively. For the geopolitical situation, see Günther Hölbl, Geschichte des Ptolemäerreiches. Politik, Ideologie und religiöse Kultur von Alexander dem Grossen bis zur römischen Eroberung (Darmstadt: Wissenschaftliche Buschgesellschaft, 1994), 174.

78. Julien Tondriau, "La tryphè, philosophie royale ptolémaïque," Revue des études anciennes 50, no. 1/2 (1948): 49-54; Heinz Heinen, "Die Tryphè des Ptolemaios VIII. Euergetes II. Beobachtungen zum ptolemäischer Herrscherideal und zu einer römischen Gesandtschaft in Ägypten (140/39 v. Chr.)," in Althistorische Studien. Herman Bengtson zum 70. Geburtstag dargebracht von Kollegen und Schülern, ed. Heinz Heinen (Wiesbaden: F. Steiner, 1983), 116-30. For syntheses, see Bernhardt, Luxuskritik und Aufwandsbeschränkungen, 246, and Kühnen, Die Imitatio Alexandri, 97-101; for bibliography, see Sabine Müller, Das hellenistische Königspaar in der medialen Repräsentation. Ptolemaios II. und Arsinoe II. (Berlin: De Gruyter, 2009), 159, n. 24.

79. For the Greek portraits, see Helmut Kyrieleis, Bildnisse der Ptolemäer (Berlin: Mann, 1975), 63-64; Sally-Ann Ashton, Ptolemaic Royal Sculpture from Egypt: The Interaction between Greek and Egyptian Traditions (Oxford: Archaeopress, 2001), 55. For an opposing view, see Roland R. R. Smith, Hellenistic Royal Portraits (Oxford/New York: Clarendon Press/Oxford University Press, 1988), no. 58, which identifies these portraits as Ptolemy IX/X. For the Egyptian portraits, see Ashton, Ptolemaic Royal Sculpture, cat. nos. 18, 19, and 21, with references for the statues of his successors.

80. Queyrel, "Le corps du roi hellénistique," 367-68, concerning Eumenes II; for the Seleucids, see Robert Fleischer, Studien zur seleukidischen Kunst, vol. 1, Herrscherbildnisse (Mainz: Philipp von Zabern, 1991), 36 (on these kings' resemblance to Tyche, goddess of prosperity) and 124 sq. (on Diodotus Tryphon).

81. See also Plutarch, Life of Antony 26.2 and 54.9, where Cleopatra dons first the robe of Aphrodite, then that of Isis. There is certainly also a feminizing aspect to the use of this chitoniskos resembling a dress: Ptolemy XII, for example, was drawn to women's clothing (such as the Tarentine robe in Lucian, Slander 16). Physcon also stripped before the Senate (Polybius, Histories 33.11.3), and thus demonstrated the extent to which the kings were able to adapt to Roman customs. Had he acted otherwise before Scipio 
he set himself in opposition to all those monarchs, good or bad, who used these elements precisely to hide their flaws and enhance their beauty-a prime example being Dionysius of Heraclea, described just before the Lagid in Athenaeus's Learned Banqueters, whose obese body was covered during audiences by an immense box which left only his head visible. ${ }^{82}$ Thus, we witness the beginnings of the fantasy of clothing which would be nothing more than a sign of the king's feats, even if they were gluttonous in nature. It was no doubt for this reason that this athlete of hedonism also acquired a slow, majestic gait, or at least a rare one, since he only went out "due to Scipio" (dia Skipiōna) or "with a cane" (dia skipōna). This amused Plutarch, who in his account has the Roman remark: "Already the Alexandrians have received some benefit from our visit. For it is owing to us that they have seen their king walk." ${ }^{83}$

\section{An Anachronistic Simplicity}

The monarchs of the Hellenistic period erased the kind of clear-cut limits implied in the opposing images of the king as affected and distant or simple and close. Kings sculpted their portraits (so to speak) and disciplined their bodies to resemble Alexander to such a degree that the full-scale display of court ceremonial rendered the frontiers traced by moralists obsolete. Later on, some would use their flesh as a space for political legitimization. However, faced with the growing interference of Rome in Mediterranean affairs, kings such as Philip V or Antiochus IV were driven to modify their costumes, setting aside their insignia to better approach their people. These two kings were evidently not the first to put on such an act: tyrants like Agathocles were past masters. ${ }^{84}$ But although such behavior certainly played a part in the classical registers of monarchical power, in these cases it took on a strategic dimension, representing a fundamental mutation of that power and serving as a rebuke to historiographers and critics.

Aemilianus, he would have been despised just the same. Prusias II, while visited by a Roman embassy, likewise set aside the royal insignia, the diadem, and his purple robes. Roman historiography treated him no better, seeing him as a king who conducted himself like a freedman, flattering his superiors and treating them like gods (Polybius, Histories 30.18.4; Diodorus Siculus, The Library of History 21.15.2; Livy, History of Rome 45.44.14). 82. Athenaeus of Naucratis, The Learned Banqueters 12.549b-d (FGrHist 432 F 10). The tyrant grew so obese that he choked to death.

83. Plutarch, Sayings of Kings and Commanders 82.13.201a.

84. The tactical ruse of removing the royal insignia in order to protect the king is not included here because it did not seem problematic to the ancients. See, for example, Plutarch, Life of Demetrius 9.5-7 and 44.9; Life of Pyrrhus 11, 13, and 17.1; Life of Aemilius Paulus 23.2; Polyaenus, Stratagems 8.57. Nor do I address the political theater of Antigonus Doson, who offered to return the diadem before being confirmed by his troops (Justin, Epitome 28.3.12): this is a topos, and very probably a literary invention, a power play supposedly used by tyrants such as Dionysius of Syracuse (Diodorus Siculus, The Library of History 12.92) or Agathocles (ibid., 20.34.2-5), and kings such as Philip Arrhidaeus (Quintus Curtius, History of Alexander 10.8.20) or Prusias II (cited above, n. 81). 
Philip V, who faced a large coalition of tribes and cities led by the Aetolians and the Romans during the First Macedonian War, not only fought an energetic campaign but also rallied a number of his allies in the peninsula through a deft use of philhellenic discourse. ${ }^{85}$ It was in this context, after the failure of peace negotiations, that in July 209 BCE Philip traveled to Nemea, drove Publius Sulpicius back to the sea, then participated in festivities at Argos: "King Philip of Macedon ... laid aside his diadem and purple robe, wishing to produce the impression that he was on a level with others and a lenient and popular prince

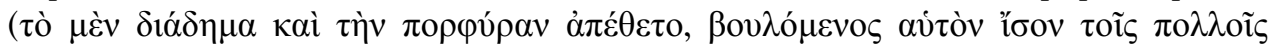

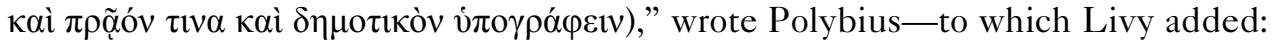
"nothing is more acceptable to free states (ciuitatibus liberis)."

As has been remarked, the Pan-Hellenic celebrations represented the agora of the Greek world to such a degree that the gesture was evidently destined to have a wide resonance. ${ }^{87}$ In Argos, moreover, it took on further meaning. The city was a symbol of Macedonian identity: it was the cradle of their status as Greeks, in the image of Alexander I, the "Philhellene." 88 They also had strong links with the Argives, as Livy later described: "Many of the Argives, too, besides believing that the kings of Macedon were derived from them, were bound to Philip by personal ties as well and by private friendship." ${ }^{89}$ It was thus the logical choice for the king, who sought to imitate the ancient Argead dynasty (a name derived from Argos), to reveal himself there..$^{0} \mathrm{He}$ himself deemed that he was engaged in a conflict

85. On this campaign, see Édouard Will, Histoire politique du monde hellénistique, 323-30 av. J.-C., vol. 2, Des avènements d'Antiochos III et de Philippe V à la fin des Lagides (1967; repr. Nancy: Presses universitaires de Nancy, 1982), 77 sq.

86. Polybius, Histories 10.26.1-2; Livy, History of Rome 27.31.4.

87. Adalberto Giovannini, "Greek Cities and Greek Commonwealth," in Images and Ideologies: Self-Definition in the Hellenistic World, ed. Anthony W. Bulloch et al. (Berkeley: University of California Press, 1993), 265-86, here p. 282.

88. Herodotus, Histories 5.22. For the debate over Macedon's place in the Greek world, see Jonathan M. Hall, "Contested Ethnicities: Perceptions of Macedonia within Evolving Definitions of Greek Identity," in Ancient Perceptions of Greek Ethnicity, ed. Irad Malkin (Cambridge: Harvard University Press, 2001), 159-186.

89. Livy, History of Rome 32.22.11. The historian is referring here to Philip's marriage to Polycratia of Argos. See John Briscoe, A Commentary on Livy: Books XXXI-XXXIII (Oxford: Clarendon Press, 1973), 211.

90. This was recognized as early as Charles Farwell Edson, "The Antigonids, Heracles, and Beroea," Harvard Studies in Classical Philology 45 (1934): 213-46, here p. 217. On the link between Philip V and the Argeads, see Polybius, Histories 5.10.10; Livy, History of Rome 27.30.9 and 32.22.11; Plutarch, Table Talk 736f. See also Supplementum epigraphicum Graecum (hereafter "SEG") 46.829, and 56.625, and possibly Inscriptiones Graecae (hereafter "IG") IV.1372.2, if one accepts Adolf Wilhelm's brash restoration (SEG 1.78). Strikingly, Philip V is represented with a beard and without divine attributes on his first series of tetradrachms, which have been variously dated from his accession, the Social War of 220-217 BCE, or, more recently, the end of his reign: Nicholas G. L. Hammond and Frank Walbank, A History of Macedonia, vol. 3, 336-167 B.C. (Oxford: Clarendon Press, 1988), 461-64. It was as if the return to the dynasty of the Argeads was accompanied by the rehumanization of the leader, or by the abandonment of overly luxuriant 
between two cultural or ethnic groups. He called on the Hellenes to block the Romans who, should they emerge victorious, "will subjugate [their Aetolian allies] as well as all the other Greeks." ${ }^{91}$

But this staging of the philhellenic credo and the equalization of conditions came to a sudden end. Philip did away with his purple robes, and with them, all restraint: "the more democratic the clothes he wore, the greater and more monarch-

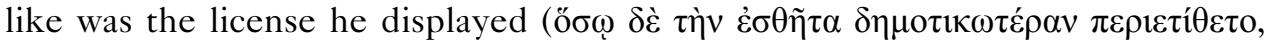

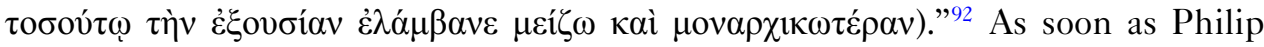
abandoned his costume, historians reduced him to a cluster of purely bodily desires that his power enabled him to sate. His conduct was subsequently considered in terms of the topos of the tyrant, with its usual array of rapes and adulteries, as well as all its galling abuses of the citizenry. ${ }^{93}$ For historians and moralists, it was inconceivable that such a "demotic" (demmotikoteran) strategy could succeed, as if the king necessarily had to distinguish himself from his people through his costume and his mores. This is no doubt a consequence of the pro-Roman orientation of the historiography, which highlighted the impossibility of abandoning the royal condition and the fictitious nature of the removal of royal insignia. Without his costume, Philip was even more sovereign (monarchikoteran), as if secrecy gave him an even greater power: to bring the wives of the citizens into his residence or pursue them through the city incognito. ${ }^{94}$

This incident, for Polybius at least, represented a turning point in the career of a king who had been superb up to that point. Antiochus IV, on the other hand, seems

dress—such a model would be taken up by Perseus: see Alfred Mamroth, "Die Silbermünzen des makedonischen Königs Perseus," Zeitschrift für Numismatik 38 (1928): 1-28. 91. Polybius, Histories 10.25.6.

92. Polybius, Histories 10.26.2.

93. See also Polybius, Histories 6.7.7, cited above, n. 70. On Livy's portrait of Philip, all crudelitas and libido, see Jacques-Emmanuel Bernard, Le portrait che: Tite-Live. Essai sur une écriture de l'histoire romaine (Paris: Latomus, 2000), 61. On the anti-civic character of the tyrant, see Pauline Schmitt-Pantel, "Histoire de tyran ou comment la cité construit ses marges," Cahiers de Jussieu 5 (1979): 217-31. There is perhaps another version of these incidents: in Plutarch, The Dialogue on Love 760a-b, an Argian notable, Phaÿllus, sends his daughter to Philip V disguised as a boy, and through this exchange of favors obtains preeminence in the city. This man possibly figures in an Argian inscription given in Pierre Charneux, "Inscriptions d'Argos," Bulletin de correspondance hellénique 77 (1953): 387-403, at p. 392, and reproduced without commentary in Jeanne and Louis Robert, "Bulletin épigraphique," Revue des études grecques 68 (1955): 185-298, no. 102, pp. 216-17. If one accepts this identification, Plutarch is painting a somber picture of what was ultimately the routine interpenetration of Hellenistic elites and the king's role in relation to local notables.

94. Compare these passages with Seneca the Younger, De Clementia 1.8.1: "Far different is the position of those who escape notice in a crowd that they do not overtop (Alia condicio est eorum qui in turba quam non excedunt latent) ... but the words and deeds of such as you are caught up by rumour, and, consequently, none should be more concerned about the character of their reputation than those who, no matter what reputation they may deserve, are sure to have a great one." Philip is condemned according to these canons: while he wishes to satisfy his compulsions, he suffers from the excessive visibility of monarchs, who cannot abandon their condition. 
to have made this political strategy into a veritable ethos. Indeed, "Antiochus, on first succeeding to the throne, embarked on a quixotic ( $\pi \alpha \rho \alpha$ á $\mathrm{o} \gamma \mathrm{ov}$ ) mode of life foreign

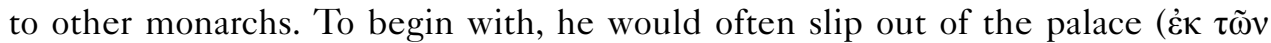
$\beta \alpha \sigma \imath \lambda \varepsilon i \omega v)$ without informing his courtiers ( $\tau \tilde{\eta} \varsigma \theta \varepsilon \rho \alpha \pi \varepsilon i \alpha \varsigma$ ), and wander at random about the city with one or two companions." 95 Polybius noted the same thing, while Athenaeus offered this summary: "He also frequently discarded his royal robes, put on a toga, and circulated through the marketplace." 96

Nothing about this behavior justifies Polybius's characterization of Antiochus as Epimanēs (the Madman) rather than Epiphaness. ${ }^{97}$ Indeed, the king merely discreetly left his palace, associated with the common people (dèmotōn anthrōpōn), ${ }^{98}$ and adopted certain traits of Roman maiestas (the toga and the curial chair). In each case, it was a matter of making himself known and recognizable to a people hitherto ruled by his brother, keeping an eye on them, and personally assuming certain magistracies or offices. ${ }^{99}$ None of these actions is in itself paradoxical, and some, moreover, were part of the king's job: we can compare, for instance, this attitude to accessibility and the exercise of justice in minor cases to that of Demetrius. Besides, Antiochus's behavior did not shock the entire population:

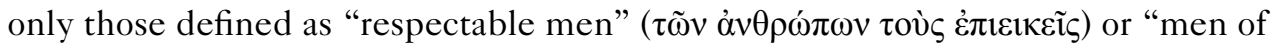

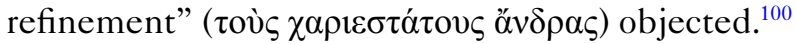

The incomprehension of these demi-savants, among whom we may count the historians, in fact stems from the labile nature of power. Regarding Antiochus, Livy noted that "so incapable was his mind of sticking to any station in life (nulli fortunae adhaerebat), as it strayed through all the varieties of existence, that it was not really clear either to himself or to others what kind of person he was (quinam homo esset)." 101 Tradition retained this image of a monarch of uncertain nature, an image that derived less from fact than from a shift in context. ${ }^{102}$ Indeed, for all intents and purposes, Antiochus IV was as lavish as the other kings. At his accession, he received all the royal regalia from the Attalids, including a costume, ${ }^{103}$ and did not

95. Diodorus Siculus, The Library of History 29.32.

96. Athenaeus of Naucratis, The Learned Banqueters 10.439a-b, summarizing Polybius.

97. Polybius, Histories 26.1.

98. Diodorus Siculus, The Library of History 29.32, and Polybius, Histories 36.1, as well as Athenaeus of Naucratis, The Learned Banqueters 10.439a.

99. Christophe Feyel and Laetitia Graslin-Thomé, "Antiochos IV, un réformateur méconnu du royaume séleucide?" in Le projet politique d'Antiochos IV, ed. Christophe Feyel and Laetitia Graslin-Thomé (Nancy: Association pour la diffusion de la recherche sur l'Antiquité, 2014), 11-47, here pp. 18-28. Otto Mørkholm, Antiochus IV of Syria (Copenhagen: Gyldendalske Boghandel, 1966), 39, already ascribed a reforming will to the sovereign. As for the monarch's adoption of Roman customs, the psychological explanation (Antiochus took them up while a hostage at Rome) seems weak, but we lack a more convincing one.

100. Athenaeus of Naucratis, The Learned Banqueters 5.193d, and Diodorus Siculus, The Library of History 29.32. See also Livy, History of Rome 41.20.1.

101. Livy, History of Rome 41.20.1.

102. Gaius Granius Licinianus 28, ed. Michael Flemisch (Leipzig: Teubner, 1904), 4-5.

103. $I G \mathrm{II}^{3} .1323 .16-19$ : the Attalids, accompanying Antiochus to the frontiers of their kingdom, helped to put him on the throne, "having provided him with money, furnished 
shy away from having himself depicted with divine attributes on his coins. ${ }^{104}$ The abandonment of the royal insignia and the preference for simpler clothing thus fit into the framework, if not of political reform, at least of an attempt to connect with an older mode of authority, based on grandeur, and perhaps to differentiate himself from Rome in the eyes of the Greeks. ${ }^{105}$ Yet this gesture proved totally anachronistic, for royalty had been structured around a distinction from the people to such a degree that it no longer resided so much in a particular physique as in the wearing of ceremonial costumes and identifiable insignia ${ }^{106}$ :

But for the diadem, no one who did not already know him would have believed that this

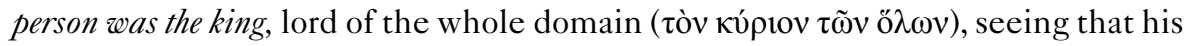

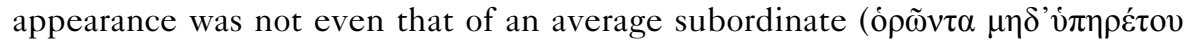

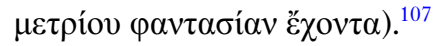

In a sense, the content of these two passages seems contradictory: Philip demonstrated his power, Antiochus his weakness. However, their authors' goal was

him with troops, crowned him appropriately with the diadem and all other suitable apparel." This text is translated into French in Paul Goukowsky, "Antiochos le fou ou Antiochos le bienheureux? Quelques remarques sur les fragments de Polybe et de Diodore," in Feyel and Graslin-Thomé, Le projet politique d'Antiochos IV, 51-74, here p. 55 , n. 18 . Goukowsky emphasizes the vestments, the horse, and the retinue (therapeia) implied by the word "apparel."

104. Olga Zolotnikova, "Visual Evidence for the Cult of Antiochos IV," Numismatica e antichità classiche 31 (2002): 239-57.

105. Mørkholm, Antiochus IV of Syria, 97, n. 33.

106. This problem is particularly apparent in accounts of usurpers in Asia around the second and first centuries BCE, when insignia were cynically used to stage political coups. Alexander Balas, tricked out with royal paraphernalia by Attalus II, overthrew Demetrius Soter in 151/150 (Diodorus Siculus, The Library of History 31.32a). Though he never became ruler, Alexander Balas's son, Antiochus VI, was adorned with royal vestments by a plotter who later assassinated him (ibid., 33.4a). The adventurer Philip Andriscus passed for a descendant of the Antigonids because he wore their garments (ibid., 31.40a and 32.15.5-7). In an ironic twist, Demetrius Soter was the only one to recognize an exiled Ptolemy in rags on his visit to Rome, and offered to dress him in royal attire (ibid., 31.18).

107. Diodorus Siculus, The Library of History 31.16.2. Following a tendency already present in Polybius, a comparative analysis of the festivities organized by Aemilius Paulus at Amphipolis and those of Antiochus IV at Daphne has been conducted: see Vincent Azoulay, "Entre familiarité et solennité. Le banquet des monarques au prisme de l'identité civique," in Le banquet du monarque dans le monde antique, ed. Catherine Grandjean, Christophe Hugoniot, and Brigitte Lion (Rennes/Tours: Presses universitaires de Rennes/Presses universitaires François-Rabelais, 2013), 53-70. This must not be taken too far, however, for it risks perpetuating an erroneous interpretation of the procession. The Megalopolitan historian wanted to present the procession at Daphne as a poor imitation of that of Aemilius Paulus. But this parallel is forced, as Peter Franz Mittag has clearly shown: see Mittag, Antiochos IV. Epiphanes. Eine politische Biographie (Berlin: Akademie Verlag, 2006), 284-85. Antiochus's event was a festival not a victory celebration. It was logical, therefore, that the king was not to be found at the head of the procession, but to the side, dressed relatively simply, as if he was attending a pompe organized by the Greeks, of whom three hundred representatives were present (Polybius, Histories 30.25.12). 
the same: to show that the king was just like everyone else once he removed the emblems of power, vicious and mediocre. It was perhaps also that the two kings shared the same project of reviving an older mode of authority in the face of Roman intervention. Philip took advantage of the Senate's distraction to strengthen his links with his allies in the Greek cities, while Antiochus adopted this conduct in order to be accepted in his kingdom and on the international scene at a moment when Roman imperialism itself presented a philhellenic face. In order to do this, it was essential to display his natural body shorn of insignia. The critiques and incredulity with which both kings were met illustrate the hostility of a historiography already smitten with Rome, but perhaps also the difficulties involved in reforming an authority that was now expected to be majestic.

This explains why one cannot produce a linear history of the royal body in the Hellenistic period, where it represents a succession of discontinuous problems. The spectrum of possibilities identified-between veiling and unveiling, naturalization and symbolization—-stretch across the ages. But the nature of power, as well as the horizon of expectations, changes over time, and in this period the choice between the alternatives became incongruous, inexplicable, and therefore worthy of being described. In reality, these processes overlapped to such a degree-alternating between a symbolization of the natural and a withdrawal of the body before the ascendance of pomp-that any periodization is undoubtedly too rigid. But three phases can perhaps be identified, each with its own share of problems. In the early Hellenistic period, a choice seems to have been made in favor of the ceremonial (more or less rapid, more or less outrageous), coupled with the transfer of some of the identifiable characteristics of Alexander's physiology into the symbolism of kingship - the natural body disappeared in favor of an all-encompassing discipline. A little later, at the turn of the second and first centuries BCE, we observe a sort of naturalization of court ceremonial, through the incorporation of truphē. The body of the king was shown off as exceptional and was enhanced by the effects of his clothing. Finally, in conjunction with the naturalization of court ceremonial, up until the middle of the first century BCE we witness the beginnings of attempts to do away with insignia that had become too constraining, and to adopt a philhellenic posture in opposition to the Romans. However, precise dates are not important here. What matters is that these mutations and reappropriations were continuously recycled without ever stabilizing around a satisfying compromise, as if to highlight the impossibility of constituting a royal body.

The question was posed from the fourth century BCE. In the writings of Xenophon, the transition from kingdom to empire presumed a reorganization of the political sphere: by tapping into the political power of pomp, Cyrus gained abundant charisma. Luxury should not, therefore, be considered according to negative or moralistic stereotypes, but rather as one of the means used by the ancient Greeks to construct a royal status. Alexander honed the system even further by adopting this pomp only in a limited and differentiated way. Despite the criticism they received, Hellenistic kings overwhelmingly adopted luxury and sought to refine 
their natural bodies into a sign of distinction. However, faced with the Roman advance, they attempted to explore other, paradoxical means of imposing their dominion. These did not always meet with success, as if splendor had by then become a natural attribute of the monarchy.

Throughout the entire period, the king's body was essentially thought of as a conduit for majesty. It would be vain to speak of the king's two bodies or of a separation between the real and symbolic, unless as a method for resolving a particular question of legitimacy, from the apology of Alexander to the spectacular gestures of Philip V or Antiochus IV. We will find no monarch who poignantly and intimately lived the separation between two persons within the same body, as would, much later, Ludwig II of Bavaria: "You yourself will soon be another man, for before your head has been anointed with [the sacred oil of coronation], know that the spirit has forbidden me the King from saluting you." ${ }^{108}$ To the contrary, Alexander used humor to remind his friends, when they witnessed his blood flowing from a wound, that it was not $i k h \bar{o} r$, the blood of the immortals; later, Antigonos the One-Eyed, when praised as a God, called to witness the guardian of his chamber pot. There is no doublethink here, only the same affirmation: all this-luxury, splendor, or divinitywas not what was essential. "As for me, I am only myself," might have exclaimed one of these sovereigns. And yet, wherever we look, we see only augmentations, postiches, accessories, all consubstantial with royalty. "What are you if not that?" one of the critics of pomp might have responded.

Yet these two statements were never set in opposition. This is because the body's boundaries were uncertain, even unstable, alternating between a substrate masked by the royal costume and an already glorious support on which to display the insignia of majesty. The body was singular, but its extension varied, depending on whether the sovereign waged war without royal pomp, made the gesture of removing his insignia in front of his people, or, like Alexander, maintained that he was untainted beneath the luxury. This lability also contained a weakness, for the interplay between the two dimensions could never cease lest the king be seen either naked or degraded by ceremonial luxury. If the incessant interaction and chiasmus between the symbolic and real remains, perhaps, the fundamental mystery of all monarchies, ${ }^{109}$ Hellenistic royalty never sought to stabilize its system, and certainly not around the king's body—as if this was a way of warding off any scission.

\section{Paul Cournarie \\ Université Bordeaux-Montaigne}

108. Journal of Ludwig II of Bavaria, cited in Louis Marin, Cross-Readings, trans. JaneMarie Todd (Atlantic Highlands: Humanities Press, 1998), 150. 